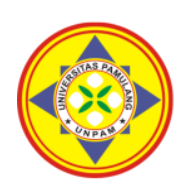
PERKVSS

\title{
PENGARUH DISIPLIN DAN MOTIVASI TERHADAP KINERJA KARYAWAN PADA KANTOR KECAMATAN SERPONG TANGERANG SELATAN
}

\author{
1Dea Pramesela, ${ }^{2 *}$ Chotamul Fajri \\ Universitas Pamulang, Tangerang Banten, Indonesia \\ *dosen01717@unpam.ac.id
}

\begin{abstract}
Abstrak
Penelitian ini bertujuan untuk mengetahui pengaruh disiplin terhadap kinerja karyawan pada kantor Kecamatan Serpong, secara parsial dan simultan. Metode penelitian kuantitatif. Populasi menggunakan teknik sampel jenuh sebanyak 58 orang. Berdasarkan hasil penelitian analisis regresi linear berganda diperoleh persamaan $Y=14,158+0,292(X 1)+0,354(X 2)$. Uji hipotesis menggunakan uji parsial variabel disiplin (X1) nilai t hitung $(2,882)>t$ tabel $(2,003)$ dan nilai signifikan $t(0,006)<0,05$ menunjukkan terdapat pengaruh disiplin (X1) secara parsial dan signifikan terhadap kinerja karyawan $(Y)$, variabel motivasi $(X 2)$ nilai $t$ hitung $(2,319)>t$ tabel $(2,003)$ dan nilai signifikan $t(0,024)<0,05$ menunjukkanbahwaterdapat pengaruh motivasi $(X 2)$ secara parsial dan signifikan terhadap kinerja karyawan (Y). Nilai F hitung sebesar $(6,852)>$ F tabel $(3,16)$ dan nilai signifikan $F(0,002)<0,05$ dapat disimpulkan bahwa terdapat pengaruh disiplin(X1) dan motivasi(X2) secara simultan dan signifikan terhadap kinerja karyawan (Y).
\end{abstract}

Kata Kunci: Disiplin, Motivasi, dan Kinerja.

\section{Abstract}

This study aims to determine the effect of discipline on employee performance at the Serpong sub-district office, partially and simultaneously. Quantitative research methods. The population used a saturated sample technique as many as 58 people. Based on the research results of multiple linear regression analysis, the equation $Y=14.158+0.292(X 1)+0.354(X 2)$ is obtained. Hypothesis test using partial test of discipline variable (X1) $t$ value $(2.882)>t$ table $(2.003)$ and significant value $t(0.006)<0.05$ indicates that there is a partial and significant influence of discipline (X1) on employee performance $(Y)$, the motivation variable (X2) t value (2.319)> t table (2.003) and the significant value $t(0.024)<0.05$ indicates that there is a partial and significant effect of motivation $(X 2)$ on employee performance $(Y)$. The calculated $F$ value is (6.852)> F table (3.16) and the significant value $F$ $(0.002)<0.05$, it can be concluded that there is a simultaneous and significant effect of discipline (X1) and motivation (X2) on employee performance $(Y)$.

Keywords: Discipline, Motivation, and Performance.

\section{PENDAHULUAN}

Peranan sumber daya manusia sangatlah penting hubungannya dengan organisasi, baik dalam organisasi pemerintah maupun organisasi swasta. Sumber daya manusia merupakan salah satu penggerak utama atas kelancaran jalannya kegiatan sebuah organisasi, bahkan maju mundurnya organisasi ditentukan oleh keberadaan sumber daya manusianya. Untuk itu setiap organisasi perlu mengawasi, membimbing dan memperhatikan keberadaan karyawan dalam mengembangkan kemampuan para karyawannya sebagai usaha meningkatkan kinerja yang baik.

Kantor Kecamatan Serpong merupakan sebuah instansi pemerintahan dimana terdapat unsur pelaksana tugas yang dilimpahkan oleh Walikota Tangerang Selatan (Tangsel) untuk melaksanakan sebagian urusan pemerintahan yang menjadi kewenangan daerah serta menyelenggarakan tugas umum pemerintahan. Kantor Kecamatan Serpong adalah sebagai tempat untuk melayani segala macam kepentingan dan urusan masyarakat sekitar yang berkaitan dengan kependudukan. Yaitu dengan melakukan 
pengurusan surat-surat dan dokumen masyarakat Kecamatan mengenai penerbitan kartu tanda penduduk (KTP), kartu keluarga (KK), penerbitan dokumen pindah datang atau pindah keluar antar Kecamatan dalam lingkup kota dan antar provinsi, mengurus data kelahiran dan kematian penduduk di Kecamatan, dan masih banyak lagi tugas yang dilakukan pada kantor Kecamatan Serpong.

Berdasarkan permasalahan tersebut pada kantor Kecamatan Serpong yang membuat kurangnya disiplin, dan kurangnya motivasi terhadap kinerja karyawan yaitu peneliti temukan pada saat observasi dilapangan adalah masih terdapatnya karyawan yang kurang disiplin dan kurangnya dorongan motivasi untuk bekerja, dengan terdapat beberapa karyawan yang datang terlambat masuk bekerja, bersantai dan keluar ruangan saat jam kerja berlangsung, mengobrol dengan rekan kerja saat jam kerja, dan pulang lebih cepat dari jadwal pulang kerja yang sudah ditentukan. Maka hal ini akan mempengaruhi kinerja karyawan yang kurang baik.

\section{TINJAUAN PUSTAKA}

Menurut Fahmi (2016:75)

"kedisiplinan adalah tingkat kepatuhan dan ketaatan kepada aturan yang berlaku serta bersedia menerima sanksi atau hukuman jika melanggar aturan yang ditetapkan dalam kedisiplinan tersebut". Menurut Hasibuan (2016:193) "mengemukakan bahwa kedisiplinan adalah kesadaran dan kesediaan seseorang menaati semua peraturan perusahaan dan norma-norma sosial yang berlaku".

Dari beberapa pengertian disiplin yang dikemukakan para ahli diatas penulis dapat menarik kesimpulan bahwa disiplin kerja merupakan suatu kesadaran atau kesedian karyawan untuk melaksanakan tugas pekerjaannya dengan tanggungjawab, mematuhi dan mentaati peraturan atau norma-norma yang berlaku dalam organisasi.

Menurut Kadarisman (2017:278) "motivasi adalah penggerak atau pendorong dalam diri seseorang untuk mau berperilaku dan bekerja dengan giat dan baik sesuai dengan tugas dan kewajiban yang telah diberikan kepadanya". Menurut Karyoto (2016:10) "motivasi adalah suatu kegiatan yang dilakukan oleh pemimpin/manajer organisasi untuk mendorong para pekerja agar bersemangat dalam melakukan pekerjaan-pekerjaan sehingga dapat mendukung tercapainya tujuan".

Dari pengertian motivasi yang dikemukakan para ahli diatas, penulis menyimpulkan bahwa motivasi adalah suatu penggerak atau dorongan dalam diri karyawan untuk melaksanakan tugas pekerjaan yang telah diberikan kepadanya demi tercapainya tujuan organisasi.

Menurut Samsuddin (2018:76) "Kinerja adalah yaitu hasil kerja secara kualitas dan kuantitas yang dicapai oleh seorang karyawan dalam melaksanakan tugasnya sesuai dengan tanggungjawab yang diberikan kepadanya". Menurut Sarmiento dan Beale dalam Maria (2018:74) "kinerja adalah sebagai hasil dari dua unsur, yang terdiri dari kemampuan dan keterampilan yang dimiliki seorang karyawan, dan motivasinya digunakan dalam melakukan pekerjaan yang lebih baik".Menurut Mangkunegara (2013:67) "kinerja adalah hasil kerja secara kualitas dan kuantitas yang dicapai oleh seorang pegawai dalam melaksanakan tugasnya sesuai dengan tanggungjawab yang diberikan kepadanya".

Berdasarkan pendapat para ahli di atas, penulis dapat menyimpulkan bahwa kinerja adalah suatu hasil kerja seorang karyawan dalam menyelesaikan tugas dan tanggungjawab yang telah diberikan kepadanya untuk mencapai tujuan organisasi.

\section{METODE}

Metode dalam penelitian ini adalah kuantitatif. Populasi dalam penelitian adalah karyawan kantor Kecamatan Serpong dengan sebanyak 58 orang karyawan. 


\section{HASIL DAN PEMBAHASAN}

Pada penelitan ini diperoleh persamaan regresi linear berganda $\mathrm{Y}=$ $14,158+0,292(X 1)+0,354(X 2)$. Dari hasil persamaan regresi linear berganda tersebut terdapat pengaruh positif antara disiplin (X1) dan motivasi (X2) terhadap kinerja (Y), maka dapat disimpulkan sebagai berikut:

a. Nilai konstanta sebesar 14,158 menyatakan bahwa jika nilai variabel disiplin $(\mathrm{X} 1)$ dan motivasi $(\mathrm{X} 2)=0$ (nol), maka variabel kinerja $(\mathrm{Y})$ bernilai tetap sebesar 14,158.

b. Koefisien regresi variabel disiplin (X1) sebesar 0,292 , artinya jika nilai variabel disiplin (X1) mengalami peningkatan 1 (satu) maka akan meningkatkan kinerja (Y) sebesar 0,292.

c. Koefisien regresi variabel motivasi (X2) sebesar 0,354 , artinya jika nilai variabel motivasi (X2) mengalami peningkatan 1 (satu) maka akan meningkatkan kinerja (Y) sebesar 0,354.

Didapat nilai $\mathrm{F}$ hitung sebesar 6.852 dan nilai $F$ tabel sebesar 3,16. Besar nilai $F$ tabel didapat dengan melihat tabel distribusi $\mathrm{F}$ dengan ketentuan rumus df 2 (n-k-1), maka diperoleh $(58-2-1)=55$. Sehingga dapat disimpulkan bahwa $F$ hitung $(6.852)>F$ tabel $(3,16)$ dan nilai signifikan $F(0,002)<0,050$. Hal ini artinya bahwa variabel disiplin (X1) dan motivasi (X2) secara serentak dan signifikan mempengaruhivariabel kinerja $(\mathrm{Y})$

\section{KESIMPULAN}

Berdasarkan hasil pengujian secara statistik diperoleh nilai $\mathrm{t}$ hitung sebesar 2.882 dan nilai signifikan $t$ sebesar 0,006 . Maka nilai $\mathrm{t}$ hitung $(2.882)>\mathrm{t}$ tabel $(2.003)$ dan nilai signifikan $t(0,006)<0,05$. Sehingga dapat disimpulkan Ho ditolak dan $\mathrm{H}_{1}$ diterima, artinya bahwa terdapat pengaruh disiplinsecara parsial dan signifikan terhadap kinerja karyawan.

Berdasarkan hasil pengujian secara statistik diperoleh nilai $t$ hitung sebesar 2.319 dan nilai signifikan $t$ sebesar 0,024 . Maka nilai $\mathrm{t}$ hitung $(2.319)<\mathrm{t}$ tabel $(2.003)$ dan nilai signifikan $t(0,024)>0,05$. Sehingga dapat disimpulkan Ho ditolak dan $\mathrm{H}_{1}$ diterima, artinya bahwa terdapat pengaruh disiplin secara parsial dan signifikan terhadap kinerja karyawan.

Berdasarkan hasil pengujian secara statistik diperoleh nilai $\mathrm{F}$ hitung sebesar 6.852 dan nilai signifikan $F$ sebesar 0,002 . Maka nilai $\mathrm{F}$ hitung $(6.852)>\mathrm{F}$ tabel $(3,16)$ dan nilai signifikan $F(0,002)<0,05$. Sehingga dapat disimpulkan Ho ditolak dan $\mathrm{H}_{1}$ diterima, artinya bahwa terdapat pengaruh disiplin dan motivasi secara simultan dan signifikan terhadap kinerja karyawan.

\section{DAFTAR PUSTAKA}

Akbar, I. R., Prasetiyani, D., \& Nariah, N. (2020). Pengaruh Motivasi Terhadap Kinerja Karyawan Pada Pt. Unggul Abadi Di Jakarta. Jurnal Ekonomi Efektif, 3(1).

AM, E. N., Sarwani, S., Akbar, I. R., Mas' adi, M., \& Maddinsyah, A. Pengaruh Kedisiplinan Dan Pemberian Kesejahteraan Terhadap Kinerja Pegawai Pada Unit Pelaksana Teknis Puskesmas Wilayah Tangerang Selatan. JENIUS (Jurnal Ilmiah Manajemen Sumber Daya Manusia), 4(2), 185-200.

AM, E. N., Sarwani, S., Akbar, I. R., Mas' adi, M., \& Maddinsyah, A. Pengaruh Kedisiplinan Dan Pemberian Kesejahteraan Terhadap Kinerja Pegawai Pada Unit Pelaksana Teknis Puskesmas Wilayah Tangerang Selatan. JENIUS (Jurnal Ilmiah Manajemen Sumber Daya Manusia), 4(2), 185-200.

Bangun, W. (2012). Manajemen Sumber Daya Manusia. Jakarta: Erlangga.

Bintoro, \& Daryanto. (2017). Manajemen Penilaian Kinerja Karyawan. Yogyakarta: Gava Media.

Ghozali, I. (2016). Aplikasi Analisis Multivariete Dengan Program IBM SPSS. Semarang: Badan Penerbit Universitas Diponegoro.

Handoko, T. H. (2011). Manajemen Personalia dan Sumber Daya Manusia. Yogyakarta: BPFE. 
Hartatik, I. P. (2014). Buku Praktis Mengembangkan SDM. Yogyakarta: Laksana.

Hasibuan, M. S. P. (2012). Manajemen Sumber Daya Manusia. Jakarta: Bumi Aksara.

Jurdi, F. (2018).Manajemen Sumber Daya Manusia: Strategi Pengelolaan SDM Berkualitas dan Berdaya Saing. Malang: Intrans Publishing.

Kadarisman, M. (2017). Manajemen Pengembangan Sumber Daya Manusia. Jakarta: Rajawali Pers.

Karyoto. (2016). Dasar-dasar Manajemen: Teori, Definisi, dan Konsep. Yogyakarta: ANDI.

Ma'aruf, A. (2016). Manajemen dan Evaluasi Kinerja Karyawan. Yogyakarta: Aswanda Pressindo.

Mangkunegara, A. A. A. P. (2013). Manajemen Sumber Daya Manusia Perusahaan. Bandung: Remaja Rosdakarya.

Maria, E. (2018). Manajemen Sumber Daya Manusia. Yogyakarta: Deepublish.

Moenir, H. A. S. (2016). Manajemen Pelayanan Umum Di Indonesia. Jakarta: Bumi Aksara.

Novitasari, E. (2017). Pengantar Manajemen. Yogyakarta: Quadrant.

Santoso, A. B., Husain, B. A., Supiandi, G., Sudarso, A. P., \& Akbar, I. R. Knowledge Sharing Melalui Motivasi Belajar Dan Pelatihan Bahasa Inggris Pada Yayasan Domyadhu Pamulang. Jurnal Pengabdian Dharma Laksana, 3(2), 106-109.

Sedarmayanti.(2017). Manajemen Sumber Daya Manusia. Bandung: Refika Aditama.

Segoro, W. (2017).Manajemen Sumber Daya Manusia: Pendekatan Teoritis dan Praktis. Yogyakarta: Deepublish.

Sihombing, S., Gultam, R. S., \& Sidjabat, S. (2015). Manajemen Sumber Daya Manusia. Bogor: Penerbit In Media.

Silaen, S. (2018).Metodologi Penelitian Sosial Untuk Penulisan Skripsi dan Tesis. Bogor: Penerbit In Media.
Sinambela, L. P. (2016).Kinerja Pegawai: Teori, Pengukuran dan Implikasi. Yogyakarta: Graha Ilmu.

Sofyan, S., Prasada, D., \& Akbar, I. R. (2020). Pengaruh Motivasi, Lingkungan Kerja dan Kepuasan Kerja Terhadap Kinerja Guru SMP/MTs Muhammadiyah. Jurnal Ilmu Komputer dan Bisnis, 11(2a), 44-55.

Sowatno. (2013). Manajemen SDM dalam organisasi Publik dan Bisnis. Bandung: Alfabeta.

Sugiyono. (2013). Metode Penelitian Pendidikan Pendekatan Kuantitatif, Kualitatif, dan RED. Bandung: Alfabeta.

Sunyoto, D. (2012). Dasar-dasar Manajemen Pemasaran. Yogyakarta: CAPS.

Sutrisno, E. (2013). Manajemen Sumber Daya Manusia. Yogyakarta: Prenada Media Group.

Wibowo. (2016). Manajemen Kinerja. Jakarta: Raja Grafindo Persada.

Wijayanto. (2014). Manajemen. Yogyakarta: Mitra Cendikia.

Wirawan. (2013). Evaluasi Kinerja Sumber Daya Manusia, Teori Aplikasi dan Penelitian. Jakarta: Salemba Empat.

Nurjaya, N., Sunarsi, D., Effendy, A. A., Teriyan, A., \& Gunartin, G. (2021). Pengaruh Etos Kerja Dan Disiplin Kerja Terhadap Kinerja Pegawai Pada Dinas Kehutanan Dan Perkebunan Kota Bogor. JENIUS (Jurnal Ilmiah Manajemen Sumber Daya Manusia), 4(2), 172-184.

Sunarsi, D. (2017). Pengaruh Kepemimpinan Dan Budaya Organisasi terhadap Kinerja Karyawan Pada Cabang Pembantu Bank DKI Pondok Labu-Jakarta Selatan. JENIUS, 1(2), 21.

Rozi, A., \& Sunarsi, D. (2020). The Influence of Motivation and Work Experience on Employee Performance at PT. Yamaha Saka Motor in South Tangerang. Jurnal Office, 5(2), 65-74. 